\title{
Obituary
}

\section{In Memoriam William M. Ballantyne}

It is with great sadness that we report that one of the founders of the Arab Law Quarterly, and a towering figure of Arab law scholarship in his own right, passed away recently at the age of 99 .

Professor Ballantyne began his career as a solicitor, and he became a barrister in England and Wales in 1977. In that capacity, and over his decades as a practicing lawyer, which remained his primary vocation, he was involved in many notable, high-profile cases respecting the Middle East and Middle Eastern law. Professor Ballantyne remained active in the English bar throughout his entire life, participating in such influential cases as Westacre v. Jugoimport [1999], Beximco v. Shamil Bank [200o], and Abu Dhabi v. H. Clarkson [2006] at an age when most lawyers have long retired.

Nearly four decades ago, Professor Ballantyne was appointed as a Visiting Professor to soAs by none other than Professor Noel Coulson and, in the intervening period, produced such well-known works as Law and Development in Arabia, Commercial Law in the Arab Middle East, and Essays and Addresses on Arab Law, with which virtually any Arab law scholar is familiar. Indeed, his Register of Laws of the Arabian Gulf, first published in 1985, was for many years the best source of Gulf Arab legislation in the English language, and it remains an invaluable resource today.

Professor Ballantyne was more than just a path-breaking lawyer and prolific scholar. He served as a member of the bar in at least three different Arab States, and he was intimately involved in the creation and evolution of Arab laws. Professor Ballantyne embodied a living history, someone who knew the Arab world, and the Arabian Gulf in particular, during a time of remarkable ferment and growth. It is to our collective immense betterment that he was able to convey that knowledge through his many writings and lectures over the decades. His vision of theory influencing practice and the reverse served as a pillar 
around which he established the Arab Law Quarterly, and it remains very much a central part of our identity to this day.

Notwithstanding these formidable accomplishments, Professor Ballantyne never lost his sense of humility and generosity, devoting much time to mentoring and developing legal minds, and teaching hundreds of students, many of whom remain influential scholars and practitioners of Arab law in their own right. He served as a colleague to some members of our Board of Editors, a faculty advisor to many others, and, in one way or another, he was a mentor to us all. As practitioners, scholars, teachers, and mentors, we remain deeply in his debt.

Over the next few weeks, the $A L Q$ will be discussing ways to properly honour Professor Ballantyne's contributions. In the meantime, we offer these few words to mourn his loss, celebrate his achievements, and express our commitment to preserving his memory.

In loving memory,

The Arab Law Quarterly 